\title{
Communication
}

[Comunicação]

\section{Histological characteristics of the corpus luteum of Nelore cows in the first, second and third trimester of pregnancy}

\author{
[Características histológicas do corpo lúteo de vacas Nelore nos terços inicial, \\ médio e final da gestação] \\ P.R. Xavier ${ }^{1}$, R.A.C. Leão ${ }^{2}$, P.V.D. Oliveira e Silva ${ }^{2}$, A.P. Marques Júnior ${ }^{3 *}$ \\ ${ }^{1}$ Aluna de pós-graduação - Escola de Veterinária - Universidade Federal de Minas Gerais - Belo Horizonte, MG \\ ${ }^{2}$ Aluno de graduação - Escola de Veterinária - UFMG - Belo Horizonte, MG \\ ${ }^{3}$ Escola de Veterinária - Universidade Federal de Minas Gerais - Belo Horizonte, MG
}

During its formation, maintenance and regression the corpus luteum (CL), a transitory endocrinal gland, presents distinct morphological characteristics and suffers intense goes through intense tissue remodeling, characterized by proliferation, differentiation and cellular death (Neves et al., 2002). It possesses a heterogeneous population of cells, with distinct morphofunctional and biochemical characteristics, classified as non steroidogenic (endothelial and pericytes cells, fibroblasts, macrophages, mast cells and leukocytes) and steroidogenic cells (O’Shea et al., 1989).

The steroidogenic cells in the luteum body are denominated large lutein cells (LLC) and small lutein cells (SLC), which can be distinguished by their size and other functional and structural characteristics (Alila and Hansel, 1984; Fields and Fields, 1996).

The small lutein cells originate from cells in the internal teca layer (Alila and Hansel,1984) and have an average diameter of $17,2 \mu \mathrm{m}$. In the pregnancy period they represent and average of $3.5 \%$ of the total number of cells in the corpus luteum and $27.7 \%$ of their volume (O'Shea et al., 1989). They possess a star shape and irregular nucleus with a densely colored nucleoplasm, large quantity of mitochondria, smooth endoplasmic reticle, lipidic drops in the cytoplasm, extensive Golgi complex (Alila and

Recebido em 24 de novembro de 2011

Aceito em 19 de janeiro de 2012

* Autor para correspondência (corresponding author)

E-mail: ampinho@ufmg.br
Hansel, 1984). They also possess a large number of $\mathrm{LH}$ receptors and are highly responsive to the stimulation of this hormone for the production of progesterone, although they secrete low quantities (O'Shea et al., 1989).

The large lutein cells originate in the cells in the granular and in the small lutein cells and have an average diameter of $38.4 \mu \mathrm{m}$ (Alila and Hansel, 1984). During the pregnancy period they are a total of around $26.7 \%$ of the total number of cells and represent $40.2 \%$ of the volume of the corpus luteum (O'Shea et al., 1989). They possess a large quantity of smooth endoplasmic reticle and sphere mitochondrion densly grouped, which indicates its great steroidogenic contribution (Fields and Fields, 1996). They present a spherical form, large circular nucleus centralized with a distinct nucleolus and dispersed chromatin, granules of lipids, a large number of secretory granules, rugged endoplasmic reticle, prominent Golgi complex and the lack of adherence junctions among cells. They are responsible for $80 \%$ of the progesterone production and have few LH receptors, which show their low response to this hormone's stimulation. They are also responsible for the secretion of oxytocin and progesterone, besides being the primary response spot to PGF $2 \alpha$ and to estrogen (Fields et al., 1992; Bertan, 2006).

The large lutein cells have dense granules measuring $150-300 \mathrm{~nm}$, which are related to their 
high steroidogenic capacity and protein synthesis (O'Shea et al., 1989; Fields and Fields, 1996). These granules are important to distinguish the large lutein cells from the small, since they are abundant in the cytoplasm of the large cells and lacking in the small cells (Fields et al., 1992).

These secretory granules contain oxytocin in the corpus luteum of the estrus cycle and relaxin in the corpus luteum of pregnancy (Fields et al., 1992). The release of oxytocin is stimulated by the PGF $2 \alpha$ of the endometrium, and it is suggested that there is a positive feedback between the luteum oxytocin and PGF $2 \alpha$ to induce the regression of the corpus luteum. The relationship observed between progesterone and oxytocin suggests that both hormones play an important role, as local and intra-ovarian factors, which reiterate the secretory function of $\mathrm{CL}$ in the cow (Rękawiecki and Kotwica, 2008).

Other types of proteins seem to be stored in the secretory granules, including the inhibitor of the metalloproteinases (TIMP) 1 and 2, which are involved in the remodeling of the corpus luteum, and the apolipoproteins E and A-1, which seem to be involved in regulating cholesterol for the steroidogenesis (Fields and Fields, 1996).

Research regarding the characterization of zebu cow (Bos taurus indicus) ovaries has been developed with the objective of knowing the ovarian physiology of this species, but in a less expressive number when compared to studies developed in cows of European origin (Bos taurus taurus). Few published work analyze the microscopical characteristics of the corpus luteum in zebu, and, thus, this work seeks to make a histological description of the luteal tissue of Nelore cows in the first, second and third trimester of pregnancy.

The experiment was approved by CETEAUFMG, under number 31/2010. 48 ovaries from cows of the Nelore race were used, all pregnant and healthy, slaughtered at Frigorífico Mata Boi, located in the city of Araguari-MG, in Triângulo Mineiro. The ovaries collected with the corpus luteum were identified and classified considering the stage of pregnancy through the size of the fetus, following the formula by Richardson (1996): $\mathrm{X}=2.5(\mathrm{Y}+21)$, where $\mathrm{X}$ is the variable "stage of pregnancy and $\mathrm{Y}$ represents the crownrump length of the fetus", constituting three groups: first group, 11 animals up to 90 days of pregnancy; the second, 20 animals with pregnancy between 91 and 180 days; and the third, 17 animals with pregnancy between 181 and 261 days.

The corpus luteum was dissected from the ovary and immersed in a plugged formalin $10 \%$ solution, for a minimum of four hours for prefixation. After pre-fixation, the specimen was sectioned in fragments of approximately $0.5 \mathrm{~cm}$ thickness in a sagittal plain, from the apex to the base, and kept in the same solution until processing. The fragments were processed according to the routine inclusion technique in paraffin, cut in microtome with a $5 \mu \mathrm{m}$ thickness, and colored with the hematoxylin and eosin technique with the objective of highlighting the nuclear and cytoplasmic structures, and in the trichromic of Gomory, to identify the conjunctive and muscular tissue. After analysis done in the plates colored with trichromic of Gomory, we decided to apply histochemical methods using the special colorations "Periodic Acid Schiff" (PAS) and Xylidine Ponceau. The evaluation of the plates was done in an optical microscope using $5 \mathrm{x}, 10 \mathrm{x}$ and $40 \mathrm{x}$ object glasses and including all the available tissue.

The corpus luteum mostly constituted in steroidogenic cells, however, the precise identification of all the large and small cells was not possible with the methodology used due to the thickness of the cut and coloring. According to Niswender and Nett (1994), a better distinction of these cells through optical microscopy would be possible through cuts in the lutein tissue, with a $1 \mu \mathrm{m}$ thickness, colored with toluidine blue. Thus, the large and small lutein cells were identified through the observation of their structural characteristics, according to the description by Sawyer (1995) and Fields and Fields (1996). The large lutein cells were classified by their spherical or polyhedral shape, large cytoplasm, large circular nucleus centralized with a distinct nucleolus. The small cells were compacted among the large cells and were identified by their irregular shape, irregular nucleus (in the shape of a goblet), smaller and less colored cytoplasm when compared to the larger lutein cell (Fig.1 and 2).

Fibroblasts were observed in the entire lutein tissue, among the collagen fibers and around the 
lutein cells (Figure 1), which presented themselves as small cells, ovoid or elongated, with an irregular cytoplasm and clear and large nucleus. According to Fields and Fields (1996), the fibroblasts are the most common cells in the conjunctive tissue and are responsible for the formation of fibers and the amorphous intercellular material. The lutein tissue presented itself full of larger and smaller arterioles, and capillaries which were mostly found among the steroidogenic cells. This high vascularization of the CL is justified due to its high metabolic demand, and, according to Wiltbank (1994), the blood flow to $\mathrm{CL}$ is greater than to any other tissue, being 65 to $95 \%$ during diestrus.

In some of the corpus luteum observed a scar was observed located in the central area of the tissue (Figure 3) and was formed by a loose conjunctive, blood and lymphatic vessels. According to Junqueira and Carneiro (2008), after ovulation some blood may flow to the cavity of the follicular antrum and, at the same time, there may be an invasion of the original conjunctive tissue of the ovarian stroma. The clot is gradually substituted and, with the conjunctive tissue, remains in the corpus luteum forming a central scar, which apparently does not interfere in the physiological activity of the corpus luteum.

When the plates colored with the trichromic of Gomory were analyzed some presented dense granules, colored red, grouped in the cytoplasm of the large steroidogenic lutein cells (Figure 4) which were not found in the small lutein steroidogenic cells. These granules did not have an occurrence pattern between the pregnancy trimesters, being observed in all stages with greater occurrence in the end of the second trimester and during the third.

In face of this finding, special histochemical colorations were done in an attempt to identify the type of granule present in cells. The first coloration used was PAS, which identifies glycogen, glucoproteins and proteoglycans. The reaction is considered positive when the region is colored in purple or magenta. The analysis of plates showed no positive reaction to PAS (Figure 5).
The Xylidine Ponceau coloring was also used in the attempt to identify the presence of protein in the cell granules. The reaction is considered positive when the region is colored orange red. A large quantity of granules colored orange red was observed in the cytoplasm of the large lutein cells, indicating that the coloring was positive for protein (Figure 6).

According to Fields and Fields (1996), the large cells in the corpus luteum possess granules in the cytoplasm which are related to their high capacity to synthesize proteins and which also differentiate them from the small cells. Fields $e t$ al. (1992), when studying taurine animals, described the secretory granules present in large quantity from the second trimester of pregnancy, which decreased significantly in the third trimester. The results of the present experiment showed that the occurrence of these granules did not present a pattern, for they were not found in all the corpus luteum evaluated, but were observed in all trimesters of pregnancy, which signals an individual response. In literature no explanation was found for such finding, nor why the trichromic of Gomory was able to color the granules present in the cells.

Comparing the histology of the corpus luteum in the three trimesters of pregnancy, we observed that the morphological characteristics of lutein steroidogenic cells did not alter. However, an increase in the conjunctive tissue, fibroblasts and extracellular matrix was observed towards the end of the pregnancy, being more pronounced after 190 days of pregnancy. Cells in degeneration were observed in all pregnancy trimesters, with greater intensity in the third trimester.

Further studies are necessary to better understand the alterations which occur in the gestational corpus luteum in the Nelore cow, mainly regarding the evaluation of apoptotic cells and the analysis of the occurrence, content and function of granules in the large steroidogenic cells found in this experiment.

Keywords: Nelore cow, pregnancy, corpus luteum, secretion granules 


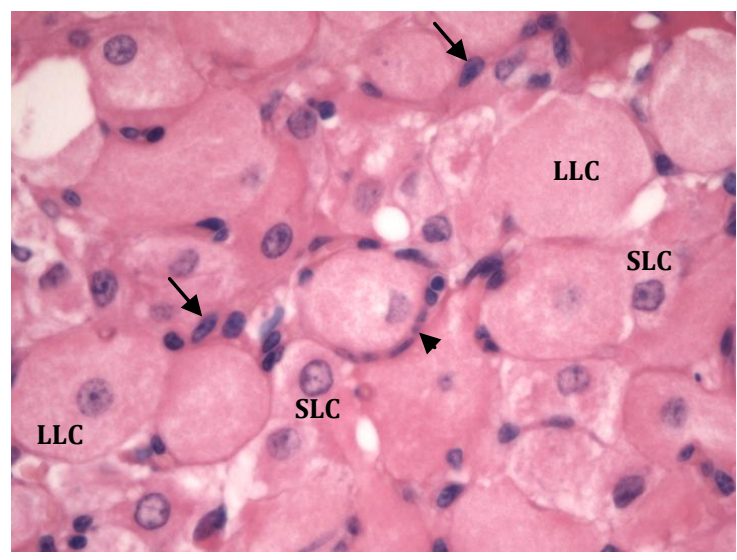

Figure 1. Nelore cow. Corpus luteum. $2^{\text {nd }}$ trimester of pregnancy, highlighting the large lutein cell (LLC), small lutein cell (SLC), fibroblasts nucleus (arrow) and fibroblasts around the steroidogenic cell (arrow head). HE-40x.

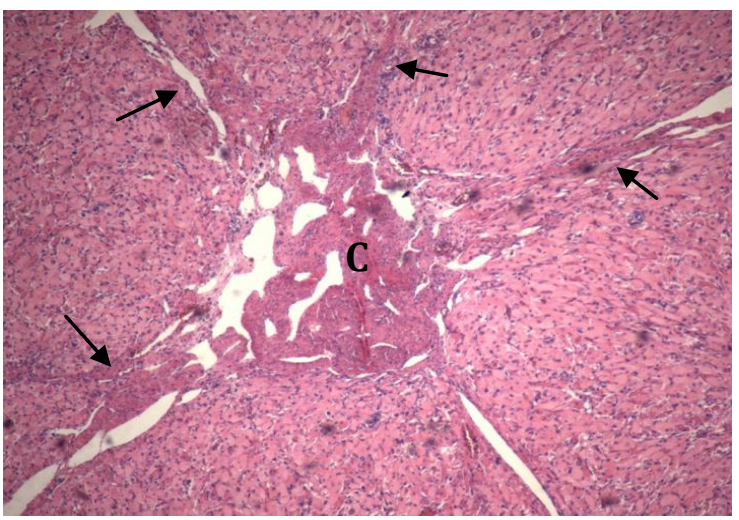

Figure 3. Nelore cow. Corpus luteum. $2^{\text {nd }}$ trimester of pregnancy with a central scar area (C) in CL and septum of conjunctive tissue (arrows). HE-10x.

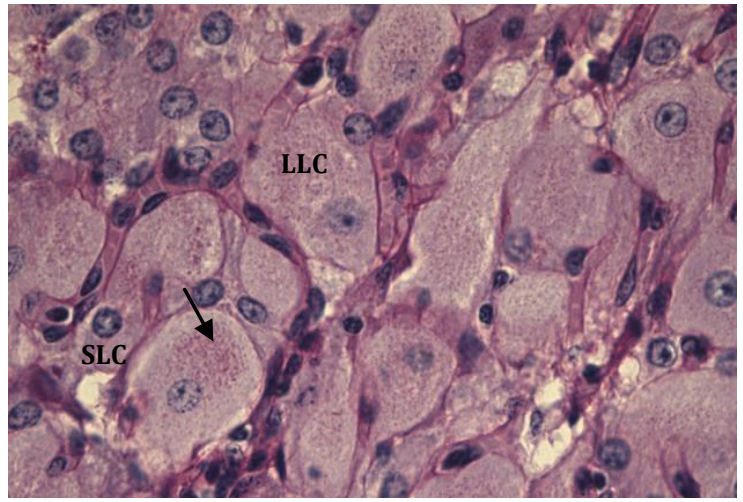

Figure 5. Nelore cow. Corpus luteum. $3^{\text {rd }}$ trimester of pregnancy, highlighting the large lutein cell (LLC) and small (SLC). It can be observed that there is little reaction of the coloring with the granules found in the cell (arrow). PAS-40x.

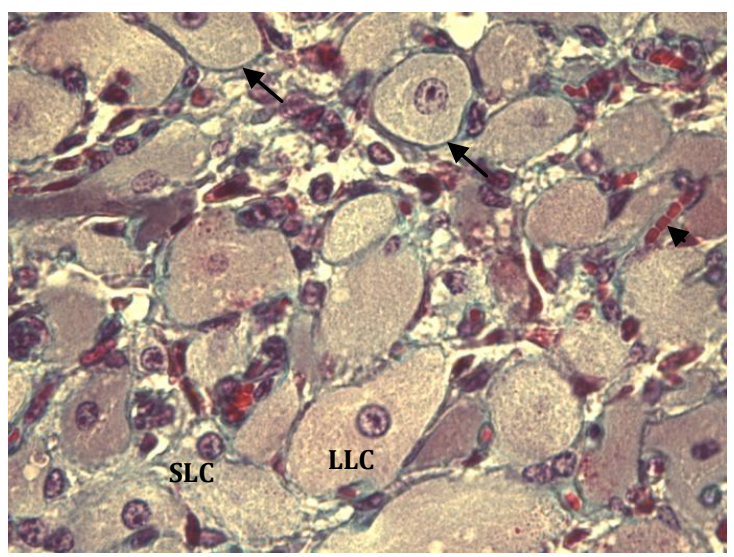

Figure 2. Nelore cow. Corpus luteum. $2^{\text {nd }}$ trimester of pregnancy, highlighting the conjunctive tissue around the steroidogenic cells (arrows), large lutein cell (LLC) and small luteinic cells (SLC) and capillary (arrow head). Trichromic of gomory-40x.

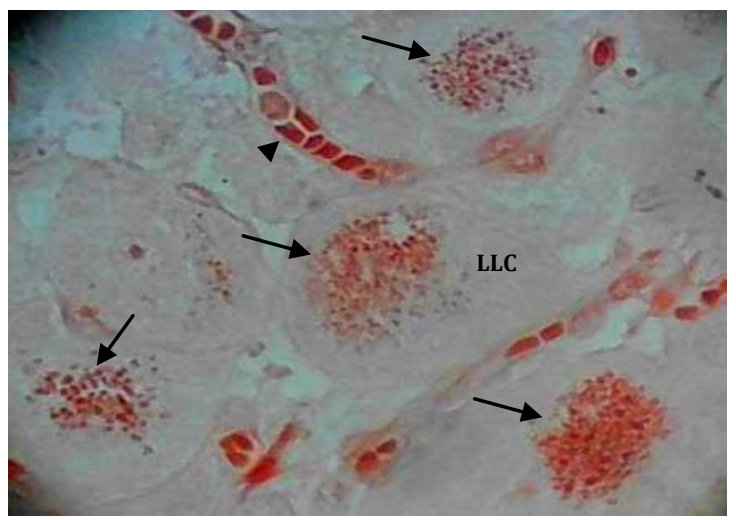

Figure 4. Nelore cow. Corpus luteum. $3^{\text {rd }}$ trimester of pregnancy with granules (arrows) present in large lutein cells (LLC) and lack of granules in the small lutein cells (SLC), capillaries (arrow heads). Trichromic of Gomory-40x.

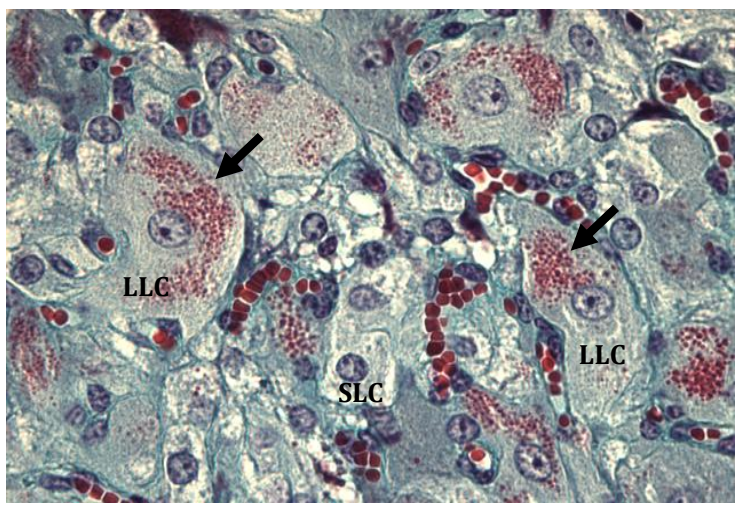

Figure 6. Nelore cow. Corpus luteum. $3^{\text {rd }}$ trimester of pregnancy, highlighting the presence of granules in the cytoplasm of large steroidogenic cells (LLC) (arrows), capillaries (arrow heads). Xylidine Pounceau-40x. 


\section{RESUMO}

Foram avaliadas características morfológicas do corpo lúteo de 48 vacas Nelore gestantes obtidos de abatedouros. Os ovários com o corpo lúteo foram coletados, identificados e divididos em três grupos, considerando o estágio da gestação determinado pelo tamanho do feto: Grupo I - onze animais com gestação até 90 dias; Grupo 2 - vinte animais com gestação de 90 a 180 dias, e Grupo 3 - 17 animais com gestação de 180 a 261 dias. Todos os corpos lúteos foram dissecados, submetidos a processamento histológico e avaliados utilizando microscopia de luz. As características morfológicas das células luteais esteroidogênicas não mudou durante a gestação. Porém, foi observado um aumento de tecido conjuntivo, fibroblastos e matriz extracelular durante o final da gestação. Células em degeneração foram observadas em todos os períodos da gestação, mas com maior intensidade no fim do terceiro trimestre. Grânulos foram observados após a coloração com Tricrômico de Gomory e Xylidine Ponceau, caracterizados como grânulos de proteína. Nenhuma explicação foi encontrada na literatura para coloração de grânulos pelo Tricrômico de Gomory.

Palavras chave: vaca Nelore, gestação, corpo lúteo, secreção de grânulos

\section{ACKNOWLEDGEMENTS}

To $\mathrm{CNPq}$, for the financial support via Grant Pesquisador and to FAPEMIG.

\section{REFERENCES}

ALILA, W.; HANSEL, W. Origin of different cell types in the bovine corpus luteum as characterized by specific monoclonal antibodies. Biol. Reprod., v.31, p.1015-1025, 1984.

BERTAN, C.M.; CESAR, M.C.; PUGINE, S.M.P. et al. Indução da ovulação em vacas com gonadotrofina coriônica humana (hCG) purificada por cromatografia de afinidade. Braz. J. Vet. Res. Anim. Scie., v.43, p.379-386, 2006.

FIELDS, M.J.; BARROS, C.M.; WATKINS, W.B. et al. Characterization of Large Luteal Cells and Their Secretory Granules during the Estrous Cycle of the Cow. Biol. Reprod., v.46, p.535-545, 1992.

FIELDS, M.J.; FIELDS, P.A. Morphological characteristics of the bovine corpus luteum during the estrus cycle and pregnancy. Theriogenology, v.45, p.1295-1325, 1996.

JUNQUEIRA, L.C.; CARNEIRO, J. Histologia Básica. 11.ed. Rio de Janeiro: Guanabara Coogan, 2008. $542 \mathrm{p}$.
NEVES, M.M.; MARQUES JR, A.P . SANTANA, C.V. et al. Características de ovários de fêmeas zebu (Bos taurus indicus) colhidos em abatedouro. Arq. Bras. Med. Vet. Zootec. v.54, p.651-654, 2002.

NISWENDER, G.D.; NETT, T.M. Corpus luteum an its control in infraprimate species. In: KNOBIL, E.; NEILL, J.D. Physiology of Reproduction, 2nd ed. New York: Raven, 1994. v.2, p.781-816.

O'SHEA, J.D.; RODGERS, R.J.; DÓCCHIO, M.J. Cellular composition of the cyclic corpus luteum of the cow. J. Reprod. Fertil., v.85, p.483-487, 1989.

RĘKAWIECKI, R.; KOTWICA, J. Involvement of progesterone, oxytocin, and noradrenaline in the molecular regulation of steroidogenesis in the corpus luteum of the cow. Bull.Vet. Inst. Pulawy, v.52, p.573580, 2008.

RICHARDSON, C. Personal communication. The development of the conceptus. In: ARTHUR, G.H.; PARKINSON, T.J. (Ed.). Vet. Reprod. Obst. 8nd ed. London: WB Saundres, 1996. p.68.

SAWYER, H.R. Structural and functional properties of the corpus luteum of pregnancy. J. Reprod. Fertil., v.45, Suppl., p.97-110, 1995.

WILTBANK, M.C. Cell types and hormonal mechanisms associated with mid-cycle corpus luteum function. J. Anim. Sci., v.72, p.1873-1883, 1994. 